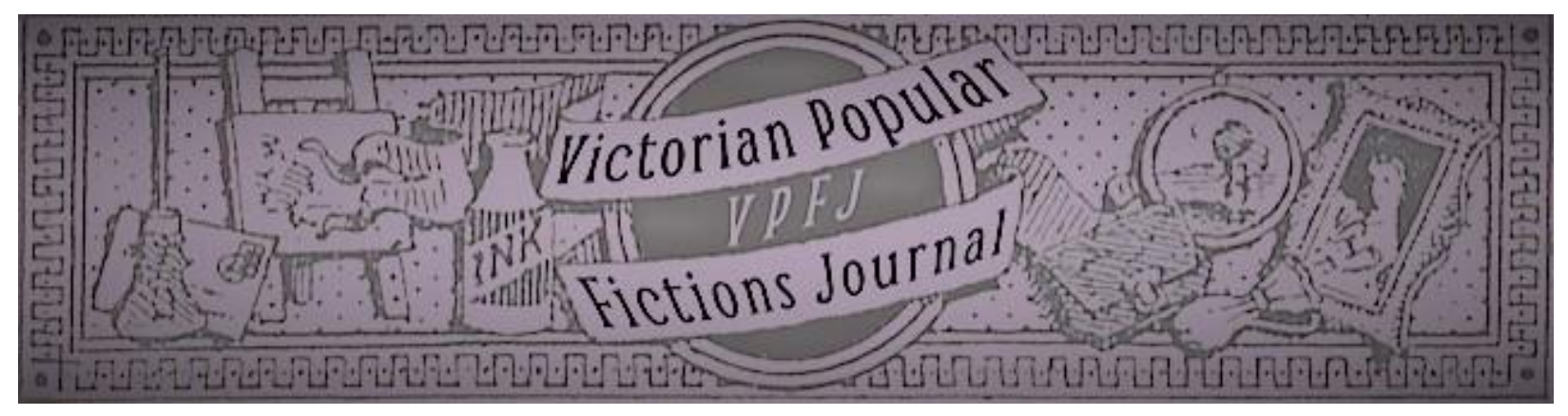

\title{
Plotting Sensation Stories: Affect and Intuition in Short Sensation Fiction
}

\section{Brittany Roberts}

\begin{abstract}
The British short story is still an understudied form in Victorian studies, and particularly so in studies of sensation fiction. Despite rich and growing scholarship on sensation fiction and its relationship with literary markets and commodity culture, scholars have a had a difficult time shaking off its enduring brand "the novel with a secret," which has problematically discounted an incredible body of periodical fiction that falls "short" of our expectations about what this kind of fiction looks like. Short periodical works, however, are crucial if we are to understand the nexus of consumerism, mass marketing, social anxiety, and literary production that first peaked in the 1860s, things which have largely come to organise our understanding of what was so sensational about this historical moment in time. This essay compares short and long works from Wilkie Collins, Charles Dickens, Ellen Wood, and J.S. Le Fanu to explore how short stories could take up common themes and features of sensation novels (mistaken identity, unchecked passion, family secrets, shocking revelations, etc.) while also considering how formal considerations of length encouraged greater reliance on impressions and feelings to resolve conflicts in the text. These sensation stories so often suggest that deviance is best discerned through the body rather than the mind, and they create a path to pleasurable revelation where trusting one's gut offers the most effective form of policing. These supposedly "unimportant" periodical works - sensational not only in the way they glutted periodicals with their sheer volume - could in turn promote suspicion and distrust in readers that were capable of damaging real-life bonds and relationships. Although short fiction could provoke anxieties about shifting roles and hierarchies in an increasingly fast-paced, automated British society, the tremendous visibility of the novel effectively shielded them from comparable criticism.
\end{abstract}

\section{Key Words}

short stories; sensation fiction; affect; intuition; Wilkie Collins; J. S. Le Fanu; Ellen Wood; periodicals.

Date of Acceptance: 1 October 2020

Date of Publication: 25 October 2020

Double Blind Peer Reviewed

\section{Recommended Citation}

Roberts, Brittany. 2020. "Plotting Sensation Stories: Affect and Intuition in Short Sensation Fiction." Victorian Popular Fictions 2.2: 41-58.

ISSN: 2632-4253 (online).

DOI: https://doi.org/10.46911/HERO5669 


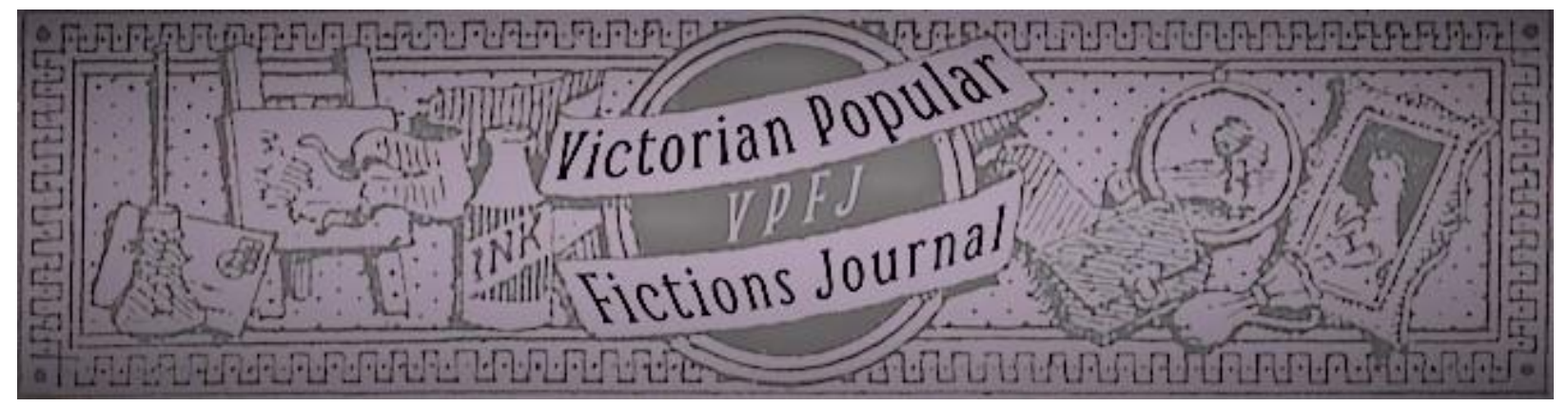

\title{
Plotting Sensation Stories: Affect and Intuition in Short Sensation Fiction
}

\author{
Brittany Roberts
}

\section{Introduction}

An affluent, spirited young woman enters into a marriage with a man whose complexion is "naturally dark and swarthy" (Collins 1858 [2004]:178). Her former husband - a man twentyfive-years her senior - has recently died. Her not-affluent new husband is strongly disliked by the family's most loyal and senior servant for inexplicable reasons, other than that he perceives in the man a "rakish, unsettled look" and a "bounceable way of talking" (150). The new husband proceeds to buy a yacht with his wife's fortune, and shortly thereafter, departs to no-one-knowswhere after an intense verbal altercation with his wife over what is made clear to readers is a platonic relationship between her and the village clergyman. An anonymous letter arrives. The mistress of the home and her lawyer confide in the faithful servant the secret of the letter, which reveals that the husband has taken another wife, a fact witnessed by the writer's own eyes. A seemingly omniscient detective is brought in. A transnational pursuit takes place. Clues are gathered. The detective knows what has happened and predicts - to the loyal servant's amazement - what will happen with the case in the future. Bigamy, a staged murder, revenge, swooning, false imprisonment, asylums - but in the end, order and truth are restored.

While this sensational plotline has all the makings of an 1860s triple-decker novel, all of its mysteries are established and solved in a mere fifty-five pages. The story in question is Wilkie Collins's "A Marriage Tragedy" (1858), ${ }^{1}$ and it is a significant one because it offers an example of how writers of the mid-nineteenth century were producing thrilling narratives of modern times in shorter forms that were raising the same kind of economic and social concerns as longer sensation novels.

\footnotetext{
${ }^{1}$ The story, which originally appeared in the February 1858 edition of Harper's, was later republished under the title "A Plot in Private Life" in Collins's short story collection The Queen of Hearts (1859).
} 
In this essay, I begin to outline how this long-neglected form adopts comparable themes and takes up similar questions as the well-studied novel but uses affect and intuition to different narrative ends within its framework of limited space. Like sensation novels, sensation stories reinforce the idea that ordinary people hide extraordinary secrets that can make what would otherwise be a very mundane world a sensational one. They likewise respond to and pose questions about human identity and changing social structures, and they do so with narratives that promote excitement and suspense over mimetic realism. Unlike novels though, the background of the families or individuals involved tends to be outlined in mere sentences rather than chapters; indeed, often when we pick up one of these stories, we are dropped immediately into the action. Comparing short and long works from Wilkie Collins, Charles Dickens, Ellen Wood, and J.S. Le Fanu reveals how short stories rely on a greater use of impressions and intuition to resolve the conflicts raised in the narrative. And while the reliance on intuition in these stories may in some ways suggest that the novel was the form better positioned to challenge ideological structures, short fiction was a marginalised, more "invisible" form that could invite greater risk-taking with endings that challenge the more conventional ones scholars have come to associate with the very visible Victorian novel. ${ }^{2}$ It is not my intention in the following examples to generalise a list of "essential" characteristics that all stories must possess to be included in the sensation genre. Rather, in heeding Dominic Head's warning that any definition of a literary form must consider "prevailing tendencies rather than essential qualities" (1992: 3), I wish to highlight how these stories - like the novel that has historically defined the genre - could provoke anxieties about shifting roles and hierarchies in an increasingly fastpaced, automated British society by staging shocking incidents as the cogs through which readers must pass to get through the narrative.

\section{The Neglected Short Story}

The British short story is still an understudied form in Victorian studies, and particularly so in studies of sensation fiction. ${ }^{3}$ Despite rich and growing scholarship on sensation fiction and its relationship with literary markets and commodity culture, scholars have a had a difficult time shaking off its enduring brand "the novel with a secret," which has problematically discounted an incredible body of periodical fiction that falls "short" of our expectations about what this kind of

\footnotetext{
${ }^{2}$ The widespread availability of short fiction in mid-century periodicals did not translate into the same kind of popularity - or sometimes notoriety - as the novel. The novel, as a key driver of magazine sales, would bear the brunt of critics' censure. I have argued earlier that Mary Elizabeth Braddon's story "Ralph the Bailiff" (1861) provides a good example of a sensational short story that presents an ending that may have been too controversial for novel form (Roberts 2018). In it, the servant interlopers' schemes go largely unpunished; they end up securing the family's wealth for themselves and living as respected citizens in Australia.

${ }^{3}$ Discussions of mid-nineteenth century short fiction have largely focused on the supernatural rather than the sensational. However, Dominic Head's edited collection The Cambridge History of the Victorian Short Story (2016) is one recent effort to explore other genres of short fiction; in it, Sophie Gilmartin's "The Victorian Pot-Boiler: Novelists Writing Short Stories" acknowledges the tendency of well-known sensation authors to write similar kinds of content in short-story forms.
} 
fiction looks like. ${ }^{4}$ Short periodical works, however, are crucial if we are to understand the nexus of consumerism, mass marketing, social anxiety, and literary production that first peaked in the 1860s, things which have largely come to organise our understanding of what was so "sensational" about this historical moment in time. At a time when literature was becoming increasingly cheap, ephemeral, and formulaic, critics saw sensation fiction as a catalyst and symptom of a new age of unthinking consumption and the key offender in the crime against high art and middle-class morality. As Harold Orel points out, short fiction published before the 1880s was looked upon by Victorian readers and magazine editors alike as mere "by-product," or "filler material" to the "central commodity" of the novel (Orel 1986: 2) - unimportant and often artistically flawed, with value that lay mostly in the entertainment the stories could provide in a moment of leisure. Short fiction as a burgeoning magazine form in Britain further supported the sense that a new market culture was effecting a shift in values that was radically changing the terms of "important" literature.

In addition to these sensational changes in the literary market that informed the short story's rise in Britain, short periodical fiction offered no shortage of sensational content (and in some cases content that was even more explicit and shocking than even the most criticised novels). Yet, given the strong association of sensation fiction with heavily plotted novels, sensation stories have received little scholarly attention. While there have been some recent attempts to expand what kinds of works "qualify" as sensation fiction and how those works might complicate our understanding of this historical moment of intense and rapid change, such efforts have been sporadic and inconsistent. Edited collections of criticism like Kimberly Harrison and Richard Fantina's Victorian Sensations: Essays on a Scandalous Genre (2006), Pamela Gilbert's Blackwell Companion to Sensation Fiction (2011), and Andrew Mangham's The Cambridge Companion to Sensation Fiction (2013) emphasise a need to expand the genre parameters and timeline of sensation fiction, and each collection includes contributions that make an effort to do so, ${ }^{5}$ but to date, there is still a real need for a comprehensive study of how

\footnotetext{
${ }^{4}$ We have taken our cue from nineteenth-century critics and moral crusaders whose censure of these popular works of crime and deviance was aimed specifically at sensation novels and novelists. Kathleen Tillotson coined the term "novel with a secret" as a way of organizing the body of work that comprised the "lighter reading of the eighteen-sixties" in her introductory remarks to Wilkie Collins's The Woman in White in 1969 (1969: xv). Later, in The Maniac in the Cellar, Winifred Hughes identifies "the sensation novel" as a unique and recognizable genre that "exploded on the literary scene" in the early 1860s and contributed to the "national state of mind known as "Sensation Mania"" (1980: 5). By the time of Patrick Brantlinger's 1982 article, "What is 'Sensational' about the 'Sensation Novel'?" the strong association of sensation fiction with the novel was becoming well-established.

${ }^{5}$ In Victorian Sensations: Essays on a Scandalous Genre, Harrison and Fantina contend that a key purpose of their collection is to "expand the limits of the sensation genre" (2006: xi), but only one essay actually engages a work that is not a novel: Nancy Welter's article "Women Alone: Le Fanu's 'Carmilla' and Rossetti's 'Goblin Market." Five years later, the Blackwell Companion to Sensation Fiction made a stronger attempt to posit forms outside of the novel as important to the genre. Indeed, as one reviewer of the collection writes, it is "particularly pleasing to see illustration [...] poetry, and short fiction [represented]; these are significant areas of research that are not readily associated with sensation fiction, a genre still very much linked to the novel" (O' Brien Hill 2011). In The Cambridge Companion to Sensation Fiction, Anne-Marie Beller's article "Sensation fiction of the 1850s" does a notable job of not only expanding sensation beyond the 1860 s but of revealing how novels written by popular sensation authors in the 1860s were sometimes derived from short stories these authors had developed in the 1850s. Still, even with these attempts at inclusivity, the Blackwell Companion as well as the Cambridge
} 
short fiction functioned - as a primarily ephemeral form - in an age marked and consumed by fears of "meaningless" consumption driven by bodily desire.

To push our thinking about the sensation genre beyond the novel is necessary when we consider how much of the reading done in this sensational moment in history was of these "filler" stories that were appearing in popular periodicals. The number of periodicals published between 1824 and 1900 exceeds fifty thousand (Orel 1986: 3), and for much of the nineteenth century, the short story in Britain was primarily a magazine form. While certainly not all periodicals were successful or popular, Dennis Denisoff has argued that "short fiction was being consumed by millions from all classes, age groups, and literacy levels," which "made it so common as to be invisible, and so popular as to be seen as unworthy of the exclusiveness associated with scholarly recognition" (2004: 17). His observation is particularly true for short fiction written before the last two decades of the century, before, as Andrew Maunder writes, the short story "came into its own" as a genre (2007: viii).

Recent studies of British short fiction in the periodical press, though still few in number, increasingly highlight the short story's relative invisibility as an artefact of mass production and what that might mean for writers whose stories could, essentially, hide in plain sight. Jochen Achilles and Ina Bergmann, for example, hint at this paradox in Liminality and the Short Story: Boundary Crossings in American, Canadian, and British Writing (2015) when they discuss the piratical impulse in British periodical publishing to take and rework (and more often, flagrantly plagiarise) short stories. Certain narratives, they argue, could become known and easily recognised without having any discernible origin (stories could even appear on different continents under different names); they could be everywhere and yet nowhere in particular, present but not "standing out." Kate Krueger, on the other hand, sees this (in)visibility differently, arguing in British Women Writers and the Short Story, 1850-1930 (2014) that the invisibility of short stories aligns with women's invisibility as important producers of cultural knowledge, even though both the stories and the women who produced them were not difficult to find. Indeed, it is well-documented that women contributed substantially to the body of short fiction published in the nineteenth century, and Krueger's position that short fiction could offer female writers a "venue in which to represent their alienation from dominant ideologies" is echoed particularly in feminist projects of Victorian ghost stories (2014: 3-4). ${ }^{6}$ In an attempt to pull short fiction out of the proverbial shadow, works like Liggins, Maunder and Robbins's The British Short Story, Amanpal Garcha's From Sketch to Novel: The Development of Fiction, and

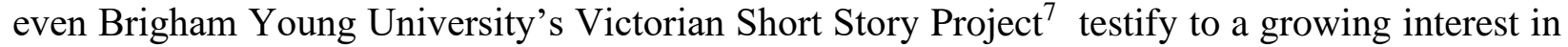
British short fiction produced before the final decades of the century; however, none of these have considered with any depth how the form evolved amid and contributed to "Sensation

Companion that appeared two years later are necessarily limited in how much space they can devote to forms outside of the novel in collections that seek to explore Victorian sensation broadly.

${ }^{6}$ Examples include Vanessa D. Dickerson's Victorian Ghosts in the Noontide: Women Writers and the Supernatural (1996), Diana Wallace's "Uncanny Stories: The Ghost Story as Female Gothic" (2004), and Melissa Edmundson Makala's Women's Ghost Literature in Nineteenth-Century Britain (2013).

${ }^{7}$ The Victorian Short Story Project is a collaborative digital archiving venture designed by the students and faculty at Brigham Young University. Stories published throughout Victoria's reign are hosted for easy access in an effort to offer a broader sense of what the Victorians were consuming in their "everyday reading" and encourage "study of the nineteenth-century short story" ("Main Page"). The stories vary widely in theme and intended audience, but all fall under fifty pages in length. 
Mania," a time when the appearance of things most inspired scepticism. And yet the evidence of an important connection between short fiction and sensation is, as all-star detective Sergeant Cuff tells his bewildered companion in The Moonstone, "as plain as the nose on your face" (Collins [1868] 1999: 181). Though the novel has played an important role in organizing our understanding of sensation fiction and the literary market in the nineteenth century, it has subsequently hidden the short story from view.

\section{Comparing Sensation Novels and Short Stories}

Sensation novels and sensation short stories have a lot in common, even though these novels are known for their long, labyrinthine plots. Both use shocking incidents as a way of calling into question social hierarchies and institutions, the role of women, and the belief in the family as the solid foundation upon which British life could be comfortably situated. Both are also centrally concerned with questions of identity - if people are not who they appear to be, then who are they really? The plots, which generally move toward a climactic revelation in response to the text's mysteries, habitually focus on policing deviant agents, which often includes an investigator of some sort (usually an amateur detective associated with the family in some way). Though formal investigations are common, behaviours are policed and disciplined using all sorts of mechanisms in these stories, and shocking crimes, excessive passions, and cruel schemes - all taking place right at home on the domestic hearth - characterise the sensation novel as well as sensational short stories.

Understandably though, for short stories, fewer staged moments of "mini climax" serve to move the plot towards its inevitable denouement, making the trajectory of revelation more direct. While both sensation stories and novels suggest that there are deviant persons at hand who need to be watched and decoded, the stories are considerably more intentional than are the novels in alerting readers to underlying corruption. These differences - a more direct path to revelation, which is made possible by (ultimately) sound assumptions about who the deviant agent is - are significant for what they suggest about how people can access knowledge about others and the world in which they live.

Intuition and "gut reactions" feature prominently in both sensation novels and stories, but where one presents these as a "puzzle" in need of a careful collection and examination of clues to rationalise the "solution," the other suggests the solution is already waiting to be found within one's feelings. Because of the shorter length of these stories, the plot is often activated by a character's (often the first-person narrator's) intense feelings of mistrust or dread toward another character or situation, and his or her emotional reactions imbue otherwise ordinary circumstances with meaning. Sensational short stories, it seems, diverge from novels in their suggestion that deviance is better discerned through the body than the mind. Plotting these affective cues within a limited narrative frame propels readers towards a foreseeable end, and in doing so, also models to great benefit how bodily response might serve to gauge duplicity more effectively than reason. These stories insist that the way one parts one's hair, the manner and tone of one's laugh, or any other innocuous detail of one's personal appearance very likely signifies an evil heart - if one feels like it does. ${ }^{8}$

\footnotetext{
${ }^{8}$ Impressions are important in sensation novels, but they are frequently misleading. For example, Robert Audley is wrong in many of his assumptions about what happened to his missing friend in Lady Audley's
} 
It is precisely this kind of suspicion that critics like Henry Mansel feared when they warned about the moral dangers of sensation novels. Mansel writes, for example, that readers may be "thrilled with horror" in imagining that the "pleasing outsides" of the good people around them could be concealing "some demon in human shape," but, he warns, "we may be permitted to doubt whether the pleasure of a nervous shock is worth the cost of so much morbid anatomy if the picture be true, or so much slanderous misrepresentation if it be false" (1863: 489). He acknowledges, "there is satisfaction in exposing an imposter" (513), and these short stories promise readers this satisfaction by engaging them in a fantasy where first impressions point to some sort of truth, for as Susan Lohafer has convincingly argued, "short fiction [...] is the most 'end conscious' of forms [and] readers of short fiction are the most 'end-conscious' of readers" (1984: 94). Indulging in such fantasies, however, could potentially impair, if not fracture, households, communities, and potentially, an entire nation, as anyone and everyone can be a suspect in a society where special talent, tools, and evidence are optional in bringing about "justice."

\section{Wilkie Collins as Storyteller and Story Writer}

In thinking about what constitutes a sensation story, it makes sense to begin with the abundant oeuvre of Wilkie Collins, who is generally regarded as the founding father of the sensation novel. Despite growing interest in Victorian Sensation and increasingly comprehensive studies of its impact on nineteenth-century British society (and beyond), and even with Wilkie Collins's reputation as an early architect of the genre, Collins's short fiction has received only marginal critical attention. His short fiction appears to have become a casualty in sensation scholarship to his well-known novels and in British short story scholarship to the persistent idea that the "real" stories of merit did not emerge until the end of the nineteenth century. Acknowledging this gap, John Bowen writes that Collins's shorter fiction deals with much "disturbing or uncanny material that cannot easily be assimilated or found a home," and he suggests that while the stories "share many qualities with his novels," they are also "significant and distinctive texts in their own right" (2006: 36-7). It is worth noting that while Collins produced many short stories over the course of his forty-plus-year career, the number of stories drops significantly during the $1860 \mathrm{~s},{ }^{9}$ his most productive decade of novel writing. Still, many of his stories published in the surrounding decades, particularly those of the 1850 s, bear strong similarities to the novels that helped make him a celebrated author.

In a fascinating unsigned review of Collins's short story collection The Queen of Hearts (1859), a key link between sensation stories and novels emerges: the importance of story-telling. What begins as an attempt to review the merit of Collins's stories repeatedly, and ironically, turns into a treatise on the function of a novel writer, a slippage which has the effect of blurring distinctions between the forms in an important way:

Secret. The Moonstone is filled with faulty ideas about who has stolen the diamond (and notably, the servant class unfairly bears the brunt of this suspicion). Betteredge, in particular, is entirely wrong in his intuitive dislike and distrust of Ezra Jennings. And who would have guessed that the good-natured Professor Pesca would be the nemesis of the evil Count Fosco in The Woman in White?

${ }^{9}$ Only three known stories were produced by Collins in this decade, all published in 1861 in All the Year Round: "Memoirs of an Adopted Son," "The Cauldron of Oil," and the "Fatal Cradle" (originally published as "Picking up Waifs at Sea" as part of Tom Tiddler's Underground in the Christmas edition). 
Both in his preface and in the body of work, Mr. Collins invites the reader to observe what is the object which the author has set before him in composing the series of tales collected under the name of the Queen of Hearts. What Mr. Collins aims at is being a story-teller. He wishes to construct a narrative the effect of which shall be to awake, sustain, and satisfy the interest of the reader. There are plenty of novels written in these days to unfold the philosophy or to instil the instruction which finds favour with the writer. There are novels in which the author attempts to elaborate character [...] novels intended to describe states of society which have passed away, or ways of life unfamiliar to the English public [...] Mr. Collins considers that all these attempts are divergencies from the proper duty of a novelist. A story-teller should have a story to tell, and should tell it. It is his business not to improve or instruct mankind, but to amuse.

(Rev. of The Queen of Hearts, Saturday Review [1859] 1974: 74)

While the short story is the form more readily brought to mind when thinking about oral traditions of story-telling, ${ }^{10}$ the repeated emphasis on the idea that "telling" a story is what Collins would consider the "proper duty of a novelist" implies the ongoing influence of this tradition at the heart of both of these forms, which is, as Henry Orel suggests, a tradition that "acknowledge[s] the presence of an audience, [while placing] an emphasis on colorful incident and verbal exaggeration" (1986:14). The idea that Collins is primarily a "story-teller" is one that reverberates in reviews of his long fiction throughout his most productive years of novel writing, with write-ups of The Woman in White (1859) indicating that "Mr. Wilkie Collins is an admirable story-teller" (Rev. of The Woman in White, Saturday Review [1860] 1974: 83), of Armadale that "He is a pure story teller" ("Recent Novels", 1866: 107), and of The Moonstone that "He is emphatically a story-writer" (Rev. of The Moonstone. Lippincott's [1868] 1974: 180). As the last (and latest) review implies, Collins was able to translate the imperatives of storytelling to a written form in a way that was so successful that it could keep a nation of anxious audience members waiting for more. Sensation fiction, after all, has long been distinguished for this unapologetic emphasis on plot.

\section{"A Marriage Tragedy"}

To return then to Collins's story "A Marriage Tragedy," the resemblance it bears to sensation novels of the 1860s is clear just in the brief synopsis of the storyline in the opening lines of this essay. Peter Haining has argued that the story bears resemblance to The Woman in White in that a "complicated family conspiracy" activates the plot, and the villainous husband of the short story, James Smith, bears a "striking resemblance" to the "evil-hearted" Percival Glyde of the novel (Haining 204: 20). It is worth pointing out that Collins might have had "A Marriage Tragedy" in mind when he began work on The Woman in White, as there appears to be a reference made to it in the early pages of the novel during Hartright's first encounter on the road with the mysterious woman in white. When she asks him to name the Baronets that he knows, Hartright responds that one was a "bachelor who had once taken [him] on a cruise on his yacht" (Collins [1859] 1998: 24). In the short story, James Smith's yacht, which he buys immediately after marrying his wealthy wife, is a symbol of greed and excess, one that makes him immediately suspicious to the loyal servant who narrates the story. That he would cruise around on it under the guise of a

${ }^{10}$ Ghost stories in particular have a strong association with orality. Frequently, for example, they begin with a narrator engaging with an audience of avid listeners as they gather around the winter hearth.

ISSN: 2632-4253 (online) 
"bachelor" makes sense for a man in search of an additional wife, and the reference is a suitable one in these early pages of the novel, as Hartright - along with readers - is being asked to speculate about identity for the first time, particularly in associating secrets and vice with people of rank and title. ${ }^{11}$ The story in some ways helps establish a trope that permeates many sensation narratives: people are rarely who they seem to be, and those who recognise this point will be best equipped to protect themselves against deception.

Although Haining sees the influence of "A Marriage Tragedy" most readily in The Woman in White, the story also bears several similarities to The Moonstone, which are worth considering at length to get a better sense of some of the larger preoccupations of sensation stories more generally. Not only does the short story feature missing jewels and supply a bloodstained nightgown as a precursor to the novel's paint-stained one, ${ }^{12}$ but it also places family secrets at the centre of an investigation while making use of narrative techniques that align readers with an amateur detective figure who models for them a desired emotional response. In "A Marriage Tragedy," readers experience the events of the story from the perspective of William, the family's servant. Much like Gabriel Betteredge, from whose perspective a large portion of The Moonstone is narrated, ${ }^{13}$ William is down-to-earth and deeply devoted to his mistress, which is why he is a logical choice when it comes to the question of whom to trust with the family secret. Despite his interest in the mystery and growing excitement about finding out the truth and origin of the mysterious letter that accuses his master of bigamy, he has little natural "gift" for detection. His plain spoken ways - "I am afraid I'm not clever enough to be of much use" $(163)^{14}$ - along with his "infernally honest" face suggests that he is an ordinary Englishman who has somehow found himself trapped in a world of extraordinary mystery (169). Having him as the story's narrator thus ensures that each time he encounters a new bit of information or a crazy coincidence, readers, too, will vacillate between shock, incredulity, and anticipation for what might happen next. Collins also makes sure to emphasise William's embodied psychological response to each new surprise as he encounters it, as if to cue a like response in readers: "My heart began to beat fast, and I felt that I was turning pale," "My flesh began to creep all over from head to foot," "I felt a burning anger [...] I was like a man who had been stunned and whose faculties had not perfectly recovered from the shock," and so on (1835). The affective responses of characters in sensation fiction (both long and short varieties) frequently model the sought-after response in readers. These responses, in turn, imbue certain events or situations with significance as both important to the plot and "real." As Ann Cvetkovich writes in Mixed Feelings, "The ambiguity of the term 'sensation' novel, which can either refer to the sensational events of the texts or to the responses they produce is not accidental. [...] Emotionally charged representations produce bodily responses that,

\footnotetext{
${ }^{11}$ The woman in white cues readers to be suspicious of these things when she says of Hartright, "Not a man of rank and title [...] Thank God! I may trust him" (Collins [1859] 1998: 24, emphasis in the original).

${ }^{12}$ While many scholars have pointed to the Constance Kent murder trial as Collins's inspiration for the paint-stained nightgown in The Moonstone, it is interesting that he makes use of a blood-stained nightgown in his short story before the famous murder (and the trial that followed it) took place.

${ }^{13}$ Betteredge's narrative is longer than any other contributor's in the novel.

${ }^{14}$ Betteredge, too, emphasises his "unfitness" for the detective role despite his budding "detective fever" in a very similar way as William when he responds to Sergeant Cuff's request for help with a modest "You don't want me [...] What good can I do?" (Collins [1868] 1999: 184-5).
} 
because they are physically felt, seem to be natural and thus to confirm the naturalness or reality of the event" (1992: 23). Perhaps this is why we readers catch detective fever alongside the characters.

For both the short story and the novel, the servant narrator is guided by a hired expert who makes use of what appears to be a kind of omniscient knowledge in order to execute his investigation, and his deductions are made all the more spectacular when related from the perspective of the humble sceptic. Whereas Sergeant Cuff serves in this capacity in The Moonstone, in "A Marriage Tragedy," the role of detective is played by the clerk of the family's lawyer, Mr. Dark, who consistently predicts events that will later come to pass. Unlike Poe's "The Purloined Letter" or later Sherlock Holmes stories, these works are not simply concerned with showcasing the brilliance of their detective figure; in fact, it is not even Sergeant Cuff who is ultimately responsible for solving the crime. Rather, they primarily concentrate on how crimes committed within a family are policed from within the family itself. Neither story is really "about" Mr. Dark or Sergeant Cuff, and yet, because they understand the world of crime, their interactions with members of the family help highlight the extraordinary world of incident and transgression into which the family has descended. Middle-class readers, who probably do not see much theft or bigamy in their daily lives, can thus identify with these average people whose experience of the emerging mysteries is extremely sensational. Their reactions are only heightened by experts who are seemingly unaffected, whose impressive experience allows them only to see the "beautiful neatness of the case" (Collins [1858] 2004: 197).

It is also worth noting that both William's and Betteredge's ignorance in all things related to detection underscores their goodness in a world of deviance, which in turn makes their strange accounts more trustworthy in a narrative that Collins has oriented toward getting at the truth. If Mr. Dark says to William, "Why, man alive [...] don't you see how it is?" (190), William does not. He will just "look at him in astonishment," to which Mr. Dark will say something like "Bless your simple heart" (190, 175). Sergeant Cuff interacts with Betteredge in much of the same way, asking him questions like, "You're not at a loss to follow me, are you?" and "You can't guess? Oh dear me, it's as plain as the stop of light there, at the end of the trees" (Collins [1868] 1999: 181). But like Mr. Dark, Cuff appreciates Betteredge's virtuous simplicity. Indeed, Betteredge's "human infirmity" and William's "simple heart" serve their families well, for as custodians of narrative, they are not only able to show the family in best possible light, but they can also highlight how the police and the law they enforce can victimise the family as much as the deviant agents from within the family itself do. This ability of the law to inflict "unjust" punishment - mostly in how it exposes the family to an "outsider," one who D. A. Miller describes as "watch[ing] what is not supposed to be watched" and "constru[ing] what he sees by other rules than the ones this community uses to regulate itself" (1998: 38) - seems to be a feature of sensation fiction both long and short.

In terms of suspense, however, "A Marriage Tragedy" and The Moonstone generate suspense differently because of their respective lengths and methods of publication. Even though sensation stories were often published in a single issue of a magazine, they still often stage moments where information is purposefully and conspicuously withheld as a way of building suspense just like the novels do. In "A Marriage Tragedy," for example, in one moment Mr. Dark will stop talking to William about some important detail related to the case because he's "too sleepy" to continue for the night (Collins [1858] 2004: 173), and if this were a serialised novel this may mark the end of the week's instalment. We can see this in The Moonstone when 
Sergeant Cuff makes the grand declaration that "Nobody has stolen the diamond" (Collins [1868] 1999: 160). Though everyone begs him to explain what he means, the instalment ends with Cuff saying, "Wait a little...the pieces of the puzzle are not all put together yet" (166). And wait readers will. A week later, when the eighth instalment begins, still no explanation is offered; readers are just as in the dark about this un-stolen stolen diamond as Betteredge and Mr. Blake. In the short story, however, the very next line after Mr. Dark declares he is "too tired to continue" is "As soon as we were awake the next morning, he returned to the subject: 'I didn't finish all I had to say last night, did I?"” (Collins [1858] 2004: 173).

These conspicuously engineered breakdowns of communication, where disclosure begins but gets cut short for some reason or another, are quite common in sensation stories. Their speedy resolution has quite a different impact from something like Marian Halcombe's final diary entry in The Woman in White, which cuts off at mid-sentence as her rain-induced illness takes over. In that case, readers would not only be left without an idea of what is to happen but also without an idea of when it will happen, as the serial can defer revelation and house all answers in an unknown future - and how far into the future, given serialization, one never quite knows. Sensation short stories are thus able to cue suspense without making anyone really agonise by waiting. They can threaten to withhold information without having the narrative means to deliver substantively on that threat. In a serialised novel, the answers to the text's mysteries are buried somewhere in the (possibly distant) future, and because that revelation can only happen in the future, it makes the inevitability of revelation more uncertain. Marian's cutoff diary entry is cut off in a very literal sense - unprinted and unavailable to readers of the serial, which is very unlike Mr. Dark's one-sentence anticipation-boosting delay.

Just as suspense is delivered upon differently in short and long sensation fiction, impressions and suspicion play a different kind of role in advancing the plots. There is, as Winifred Hughes pointed out, a "recurrent preoccupation with the loss or duplication of identity" (1980: 21) in sensation fiction, and this is true for both long and short forms. This is familiar territory in novels with well-known examples like Lady Audley, or Lady Isabel from East Lynne, or even something like Laura Fairlie and the Anne Catherick mix up in The Woman in White, or Franklin Blake being the jewel thief without actually knowing it in The Moonstone. In short fiction, too, examples abound. In Collins's "The Lady of Glenwith Grange" (1856), a young woman finds that she has married an imposter with an "extraordinary likeness" to the real person she was marrying. Braddon's "The Mystery at Fernwood" (1861) features an "idiot" twin who, after being locked in a hidden room in the house for twenty years, successfully escapes and kills his well-loved, able-bodied brother with a pen-knife to the neck just days before his wedding. And stories like Eliot's "The Lifted Veil" (1859) and Collins's "The Dream Woman" (1855) feature visions of hateful - sometimes murderous - women who materialise as "real" people by the story's end.

In sensation fiction, secrecy and the body go hand in hand, and while both sensation novels and stories are concerned with reading bodies, short stories tend to highlight "problem" bodies early on by featuring characters who experience "unnatural," unprovoked suspicion towards them. This suspicion rarely arises as a reasoned response to behaviour. Rather, characters are moved by inexplicably strong feelings - feelings that occur in the "gut," so to speak, rather than the head. These impressions inspire them to question or fear particular people, which then becomes a driving anxiety of the story that demands resolution. Whereas a sensation novel might begin by introducing an event that puts the sensational plot in motion - an escaped 
asylum patient wandering on the street, a stolen diamond, a missing wife, etc. - a sensation story more often highlights a questionable body, someone who needs to be scrutinised and deciphered. Notably, in sensation novels, impressions are often completely wrong, something more like a false hint (as we see, for example, with Betteredge's distrust of Ezra Jennings).

In contrast, we have a short story like Charles Dickens's "Hunted Down," which revolves around a life insurance manager's attempt to pursue and prosecute - to "hunt down" - one Mr. Julius Slinkton, who he believes - based on nothing but a strong impression - to be an unfeeling scoundrel and nefarious poisoner. Readers are told at the beginning of the story that Sampson "conceived a very great aversion to that man the moment [he] saw him" (Dickens [1859] 1992: 49). Sampson presents himself as an expert in physiognomy, a role for which he is fitted because of his position at a "Life Assurance Office," where the most "crafty and cruel of the human race" practice their misconduct (49). Readers, dutifully, believe him.

Although Sampson does have some doubts about his investigation while he attempts to "hunt down" Slinkton - at one point he capitulates that it may indeed be "monstrous" to "suspect [...] and detest" a man based on the way he parts his hair - ultimately his initial suspicion that Slinkton was "not quite genuine" is proven correct (52-3). Interestingly, Sampson uses the same logic that Robert Audley will later use in Lady Audley's Secret about circumstantial evidence when he says, "An observer of men who finds himself steadily repelled by some apparently trifling thing in a stranger is right to give it great weight. It may be the clue to the whole mystery. A hair or two will show where a lion is hidden. A very little key will open a very heavy door" (Braddon [1862] 1998: 53). ${ }^{15}$ In the short story, readers can truly trust their gut when it comes to these "trifles."

Dickens's "Hunted Down" offers one example of how sensation stories could effectively economise plot by using affective response as a mechanism for successful policing, but this paradigm holds up across many examples of the form. It is particularly helpful to look at short stories that were later developed into novel-length serials. Both Ellen Wood and J.S. Le Fanu, for example, built novel-length works from short works previously published in periodicals, and these examples help to demonstrate how clues about problematic identity in novels work more like overt warnings in short stories. Wood's third-person sensation story "St. Martin's Eve" (1853) is later developed into the novel by the same name in 1866, and Le Fanu's first-person narrative "The Murdered Cousin" (1851) ${ }^{16}$ later becomes Uncle Silas in 1864. Although both Wood and Le Fanu's novels have been embraced as sensation novels, not surprisingly, the stories out of which these novels developed have received little critical attention.

\footnotetext{
${ }^{15}$ Although Robert has no evidence to accuse Lady Audley of a crime, he attempts to frighten her into submission by talking about the power of circumstantial evidence: "Upon what infinitesimal trifles may sometimes hang the whole secret of some wicked mystery, inexplicable heretofore to the wisest upon the earth!” (Braddon [1862] 1998: 123).

${ }^{16}$ An earlier version of "The Murdered Cousin" appeared in Dublin University Magazine under the title "A Passage in the Secret History of an Irish Countess" (1838). A final version of the story is published in a posthumous collection called The Purcell Papers (1880).
} 


\section{From "St. Martin's Eve" to St. Martin's Eve}

Only recently has "St. Martin's Eve" been described as an important precursor to Wood's success as a sensation writer in the 1860s, which Anne-Marie Beller effectively argues in her 2013 exploration of 1850 s sensationalism. Beller points out that "the sensation fiction produced by Wood in the 1860s was often not new at all" given that many of her short stories served as "early versions" of her novels, and she echoes Andrew Mangham's claim in Violent Women and Sensation Fiction (2007) when she asserts that the 1853 story-version of "St. Martin's Eve" is "decidedly more disturbing" than any of the fictional crimes depicted in the following decade (2013: 16). Although the short story and novel diverge in some ways, the general story arc of each is quite similar: a second wife, consumed by jealousy, murders her husband's child by his first wife to enable her own son to become heir to the estate.

While both the novel and short story are clearly "sensational" in their focus on incident as a way of working through questions about the stability of the family and women's place as its foundation, Beller claims that the story is "arguably more sensational" than the novel primarily for two reasons. The first is the manner of the child's death, which is brought about by Charlotte locking him in a burning room in the novel but by her holding him with a "firm, revengeful hand, beating him about the head and ears" until the "blaze [catches] his pinafore" in the short story (Wood 1853: 337). Thus, in the story, it is only after the boy is first held down in the fire that she then locks him in the room to leave the "ill-fated child to burn slowly away to death" (337). The second is that Charlotte is a "more nuanced" character in the novel than she is in the story (Beller 2013: 16), for unlike the story that depicts her as emphatically and conclusively evil, in the novel she has moments when she is actually at times moved to kindness toward her stepson, and the beatings are not so graphically depicted. Here, without quite saying it, Beller picks up on a key difference between sensation stories and novels for which I have been making a case: stories often direct readers' attention to deviance more quickly and with less deliberation about its roots or gradations, and they chart a clear path to resolution through policing that corrupt agent, using affect (rather than logic) as a guide to action.

As a third-person narrative, "St. Martin's Eve" does not filter information about the villain through the impressions of a biased first-person narrator in the way that "Hunted Down" or Le Fanu's "The Murdered Cousin" do; however, the omniscient narrator is still able to evoke a strong feeling of instinctual fear in readers toward Charlotte by introducing her as "beautiful [...] but not pleasing," suggesting that although she was "tall and finely formed," in her "jetblack eye and compressed mouth," there "might be read an expression strangely disagreeable" (Wood 1853: 329). Without yet knowing anything about this young woman or her history, eager readers are invited to read into her character and motivations, and a discriminating reader will certainly take up the cue to recognise evil in those compressed lips if it "might be read" there (329, my emphasis). It is an example of what Anna Maria Jones calls the "paradoxical pleasure" of reading sensation fiction, of being "simultaneously 'in' the mystery, invited to follow along and glean clues" and "outside the text, knowing more than a character 'embedded' in the narrative" (2007: 5). Although the unsuspecting George Carlton might not know how to read the signs in his future wife, the discerning reader can feel when things are not quite right, even if that feeling is based solely on the characterization of a slight grimace of the mouth. Readers believe that Charlotte will be bad even before she has actually done anything bad. Wood offers a quick return on readers' suspicion, as within two pages Charlotte becomes the wife of Carlton, has a child of her own, and breaks out into a violent, jealous fit at the sight of her husband playing 
with his first son, still at that point a young toddler. The text confirms Charlotte's deviance by asserting that "to many a woman this might have been a pleasant sight," but for she who "during her girlhood [...] had been subject to fits of ungovernable rage, so violent, that they seemed to fall little short of insanity" it produces feelings that trigger a "fiendish expression of face" and move her to the kind vicious brutality that inspires throwing a happy toddler violently on the floor while onlookers watch in stunned, silent horror (Wood 1853: 331-2). Of course, readers never thought this story was going to end with a happy marriage.

Charlotte's introduction in the novel, on the contrary, does not signal the inevitable ending of the plot like it does in the short story because it is missing clear affective cueing. When Charlotte is first described in the novel, her expression is not characterised as "strangely disagreeable," but instead as one that "none could fathom," a "sort of wild expression of absolute will" (Wood 1866: 20, emphasis in the original). While such a characterization signals that she is a person of interest, and while wilful female characters are habitually problematic in Victorian fiction, it does not have an overtly negative edge to it, and the reader likely wonders what she might do or what she might be capable of doing - bad or good. After all, given that her mother will spend a good deal of time warning her about the plight of a second wife (even though a large fortune is up for grabs through the union), Charlotte's "will" to marry George St. John even if she should have to "beg [her] bread afterwards from door to door" actually seems quite noble in its apparent espousal of romantic love (27). Unlike the short story then which creates evidence out of feelings and rewards readers with a pleasurable payoff for trusting their gut, the novel offers little in the way of preparing readers for the shocking violence Charlotte will unleash much later in the text.

Although Charlotte ends up in an asylum in both the novel and short story, her guilt hinges on different things: in the story, people in the town only begin to speculate that she committed the crime after her emotional breakdown lands her in the asylum, whereas in the novel, the locked nursery door serves as hard evidence of the crime. Ultimately, not unlike readers of the short story who sense Charlotte will do something terrible based on her grimace, those characters in the story who feel she has committed the crime based on a mental breakdown that occurs a year after the fact access truth through what Srdjan Smajic calls in his study of vision and the supernatural "intuitive knowing [...] supplemented with evidence gathered through the exterior senses" (2010: 45). ${ }^{17}$

\section{From "The Murdered Cousin" to Uncle Silas}

Like Wood, Le Fanu significantly alters the way in which he characterises his villain in the novel-length version of his short story, transforming Uncle Silas - the "inscrutable" entity upon whom the novel of the same name centres (Le Fanu [1864] 2009: 229) - from a character whose villainy is a conspicuous and startling truth in short-story form to one where it is a much more subtle possibility in the novel. ${ }^{18}$ While there are some notable differences in the short story and

\footnotetext{
${ }^{17}$ In the novel, conversely, what Andrew Mangham calls Charlotte's "external blankness" is so effective that it "reflect[s] and refract[s] the interpretive, subjective gaze of her observers" (2007:79).

${ }^{18}$ It is worth noting that, in terms of categorization, Le Fanu's work has posed some difficulty for scholars, with some insisting that his fiction more logically serves as an extension of the gothic rather than an example of sensation fiction (Zuber 2006: 74). Le Fanu himself did his best to avoid the label of sensation novelist, going as far as to beg readers in the "Preliminary Word" of Uncle Silas to "limit that
} 
the novel, the general plot of each is quite similar, although the story accomplishes in thirty pages what the novel does in sixty-five chapters and a conclusion. A young woman with a large fortune becomes a pawn in her well-meaning father's plan to lift the blanket of suspicion that has for many years since enshrouded his ill-fated brother, and in doing so, help redeem the family name. Accused - but not convicted - of murdering a fellow gaming man to whom he owed a large sum of money, the "reformed" profligate (Uncle Silas) is named as the girl's guardian in her father's will, which is revealed upon his death. The most alarming part of all this is that an addendum to the will has been added to assert that if the girl dies before she comes of age, the entire fortune shall pass to her guardian uncle. Thus, believing that his brother is innocent, the judicious father leverages his daughter's life to prove the integrity of a man whose character has been a matter of public debate since she was a small child.

Depicting Silas as a more "enigmatic" character in the novel has engendered some unfair criticism of the "The Murdered Cousin," the story out of which Uncle Silas evolved, with Audrey Peterson lamenting that it lacks "the rich development of character [...] achieved in the novel" (1984: 143), while Michael H. Begnal further reduces the story to one where "the point is purely entertainment" (1971: 30). These observations clearly echo early criticism of sensation novels (and thus forge a preliminary connection between the story and the genre), while also working to undercut the text's provocative social commentary. "The Murdered Cousin" has all of the makings of a sensation novel in just a fraction of the space - murder, mistaken identity, an orphaned heroine, intercepted letters, and an evil uncle - but it also highlights how existing legal and social arrangements can make women most vulnerable to violence in their own homes among their own families. ${ }^{19}$ The short story, like the novel, creates a world where women's bodies are akin to property, and owning or destroying those bodies (through marriage or murder) are the logical channels of financial speculation for ruined men. If Silas is a less ambiguously dangerous character in the short story, it only serves to highlight the fact that the heroine is victimised by the mistaken belief that sharing a family name will ensure honour, loyalty, and goodwill. That readers can see the threat posed by Silas that the heroine's own father clearly cannot, and that they must watch as she steadily descends into a precarious trap that might have otherwise been avoided, makes their feelings of dread a better arbiter of truth than the "rational" response of trust and duty to one's family. The novel, in contrast, keeps readers more closely aligned with the heroine and not privy to Silas's intentions, creating a tension between instinct and prejudice that makes readers more wary about forming judgments. The unwavering belief in the unfailing strength of blood ties and honour - whether the deviant agent is an obvious one (as it is in the case of the short story) or possibly one (in the case of the novel) - is, as sensation fiction of all lengths proves again and again, an imprudent and ultimately dangerous worldview.

Several critics have pointed to the fact that "The Murdered Cousin" offers an early example of the "locked room mystery" story popularised by Poe's "The Murders in the Rue Morgue" (1841), and while the "impossible" murder scenario described in the story lends itself

degrading term" and see his work as part of the "legitimate school of tragic English romance" ([1864] 2009: vii); however, instead of likening his work to Walter Scott's (whom he very much admired), he was deemed "the Irish Wilkie Collins" by his reviewers and has since maintained an increasingly firm position within sensation scholarship today.

${ }^{19}$ Kimiyo Ogawa has identified this as a key departure from the gothic tradition; in making the threat come from within the family unit itself, Le Fanu "renders the gates that are supposed to protect the female victim from the outside ineffectual [...] as she finds danger within" (2007: 19). 
to such a description, the concept is also rhetorically useful for thinking about Victorian sensation stories as a closed, structured form that invites "working out" within a controlled structural context. The "locked room mystery" is a subset of detection fiction that presents a situation where a crime (usually a murder, but not always) has been committed in under what appear like impossible circumstances. The "locked room" refers to a crime scene where it would be impossible for the criminal to have escaped. As Michael Cook points out, "The locked room mystery is a form which [...] gives the fullest expression to the elements of closure and enclosure" (2011: 6), and the room can only "open up" through the process of reading. This is also the case for sensational short stories, where the solution to the mystery, the identity of the villain, the final shocking surprise is always close enough at hand to bring closure to and escape from the text relatively quickly. Conversely, rather than promising closure in the form itself, serialised novels resist such closure. Readers might "finish" an instalment but would ultimately find themselves stuck in a narrative where closure is habitually deferred, and editors would also exert great effort in promoting whatever new serial would follow to ensure that readers would remain loyal buyers. In addition, not only did serialization "elongate" narratives - to use Julia McCord Chavez's phrasing (2010: 798) - and guarantee recurrent purchasing, but serials also promised to be reissued in triple-decker forms that could then be bought, shared, and cycled through Mudie's unyielding turnstile. While short stories might be republished in a collection, there was virtually no end to the novel, of which we can readily find evidence in the preoccupations of our own scholarship.

Expanding our study of sensation fiction to include short stories is promising for future studies of the sensation genre. In truth, the sensation novel's embrace of secrets, crime, excess, and violent passions, as well as its preoccupation with social disorder and the collapse of the family are not actually unique to the novel at all. Short stories not only engaged similar themes and made comparable social commentary as the novel, but they could also, as in the case of "St. Martin's Eve" for example, be at times even more explicit in their treatment of incident than the novels that were so frequently attacked for their moral ambiguity and questionable literary merit. These stories could also contribute in a significant way to a culture in which production and automation - rather than taste - increasingly informed reading practices. Given that novels were seen as the central commodity of the magazine, short stories - as filler - became the mere "stuff" of thoughtless consumption at a time when anxiety around passive consumption threatened to upend Britain's claims to moral and intellectual superiority. And if the British public did indeed have a "diseased appetite" as Henry Mansel feared, then the short story was, to use Liggins, Maunder, and Robbins's term, the perfect "cheap literary snack" (Liggins, Maunder, and Robbins 2011: 27). Sensation stories could subvert cultural narratives that trumpeted self-control by demonstrating time and time again the value of intuition and impulse. These stories, after all, so often conclude that one's worst and most immediate suspicions about one's neighbour, the cheery country maid, or even one's own spouse are well-placed, and readers would do well to view the characters of their own lives through a lens of healthy suspicion. As magazine ephemera, sensation stories could challenge dominant cultural discourse while evading criticism, and it is essential that we as scholars recognise them as a meaningful and important part of the genre if we are to do justice to the scope, forms, and impact of sensation fiction. 


\section{Bibliography}

Achilles, Jochen and Ina Bergmann, eds. 2015. Liminality and the Short Story: Boundary Crossings in American, Canadian, and British Writing. Abingdon: Routledge. DOI: https://doi.org/ $10.4324 / 9781315817040$

Begnal, Michael H. 1971. Joseph Sheridan Le Fanu. Lewisburg: Bucknell University Press.

Beller, Anne-Marie. 2013. "Sensation Fiction in the 1850s." In The Cambridge Companion to Sensation Fiction, edited by Andrew Mangham, 7-20. Cambridge: Cambridge University Press. DOI: https://doi.org/10.1017/CCO9780511675744.003

Bowen, John. 2006. "Collins's Shorter Fiction.” In The Cambridge Companion to Wilkie Collins, edited by Jenny Bourne Taylor, 37-49. Cambridge: Cambridge University Press. DOI: https://doi.org/ 10.1017/CCOL0521840384.004

Braddon, Mary Elizabeth. [1861] 1867. "The Mystery at Fernwood.” Temple Bar (Nov. - Dec.). In Ralph the Bailiff and Other Tales, 88-120. London: Ward, Lock, and Tyler.

Braddon, Mary Elizabeth. [1862] 1998. Lady Audley’s Secret. London: Penguin.

Brantlinger, Patrick. 1982. "What is so 'Sensational' about the 'Sensation Novel'?" Nineteenth-Century Fiction, 37.1: 1-28.

Chavez, Julia McCord. 2010. "The Gothic Heart of Victorian Serial Fiction." Studies in English Literature, 50.4: 791-810.

Collins, Wilkie. [1855] 2004. “The Dream Woman.” In Wilkie Collins: Sensation Stories, edited by Peter Haining, 87-111. London: Peter Owen.

Collins, Wilkie. [1856] 1912. "The Lady of Glenwith Grange.” After Dark, 275-300. New York: Dodd, Mead, and Company.

Collins, Wilkie. [1858] 2004. “A Marriage Tragedy.” Harper's New Monthly Magazine. 16.93 (February): 334-57. In Wilkie Collins: Sensation Stories, edited by Peter Haining, 149-205. London: Peter Owen.

Collins, Wilkie. 1859a. “A Plot in Private Life.” The Queen of Hearts. Project Gutenberg.

Collins, Wilkie. 1859b. The Queen of Hearts. Project Gutenberg.

Collins, Wilkie. [1859c] 1998. The Woman in White. Oxford: Oxford University Press.

Collins, Wilkie. [1868] 1999. The Moonstone. Toronto: Broadview Press.

Cook, Michael. 2011. Narratives of Enclosure in Detective Fiction: The Locked Room Mystery. New York: Palgrave. DOI: https://doi.org/10.1057/9780230313736

Cvetkovich, Ann. 1992. Mixed Feelings: Feminism, Mass Culture, and Victorian Sensationalism. New Brunswick, NJ: Rutgers University Press.

Denisoff, Dennis. 2004. "Introduction." The Broadview Anthology of Victorian Short Stories, 11-27. Toronto: Broadview Press.

Dickens, Charles. [1859] 1992. "Hunted Down." In Victorian Tales of Mystery and Detection: An Oxford Anthology, Edited by Michael Cox, 48-68. Oxford: Oxford University Press.

Dickerson, Vanessa D. 1996. Victorian Ghosts in the Noontide: Women Writers and the Supernatural. Columbia: University of Missouri Press.

Eliot, George. [1859] 2015. “The Lifted Veil.” Lexington: World Library Classics.

Garcha, Amanpal. 2009. From Sketch to Novel: The Development of Victorian Fiction. Cambridge: Cambridge University Press. 
Gilbert, Pamela K., ed. 2011. A Companion to Sensation Fiction. Chichester, West Sussex: WileyBlackwell. DOI: https://doi.org/10.1002/9781444342239

Gilmartin, Sophie. 2016. “The Victorian Potboiler: Novelists Writing Short Stories." In The Cambridge History of the Victorian Short Story, edited by Dominic Head, 67-83. Cambridge: Cambridge University Press. DOI: https://doi.org/10.1017/9781316711712.005

Haining, Peter, ed. 2004. Wilkie Collins: Sensation Stories. London: Peter Owen.

Harrison, Kimberly, and Richard Fantina, eds. 2006. Victorian Sensations: Essays on a Scandalous Genre. Columbus: Ohio State University Press.

Head, Dominic, ed. 2016. The Cambridge History of the Victorian Short Story. Cambridge, Cambridge University Press. DOI: https://doi.org/10.1017/9781316711712

Head, Dominic. 1992. The Modernist Short Story: A Study in Theory and Practice. Cambridge, Cambridge University Press. DOI: https://doi.org/10.1017/CBO9780511735356

Hughes, Winifred. 1980. The Maniac in the Cellar: Sensation Novels of the 1860s. Princeton, Princeton University Press.

Krueger, Kate. 2014. British Women Writers and the Short Story, 1850-1930: Reclaiming Social Space. New York: Palgrave. DOI: https://doi.org/10.1057/9781137359247

Jones, Anna Maria. 2007. Problem Novels: Victorian Fiction Theorizes the Sensational Self. Columbus: Ohio State University Press.

Le Fanu, Joseph Sheridan. 1838. "A Passage in the Secret History of an Irish Countess." Dublin University Magazine, 12: 502-19.

Le Fanu, Joseph Sheridan. 1851. "The Murdered Cousin." In Victorian Tales of Mystery and Detection: An Oxford Anthology, edited by Michael Cox, 18-47. Oxford: Oxford University Press.

Le Fanu. [1864] 2009. Uncle Silas: A Tale of Bartram-Haugh. Hertfordshire: Wordsworth Edition.

Liggins, Emma, Andrew Maunder, and Ruth Robbins. 2011. The British Short Story. London: Palgrave Macmillan.

Lohafer, Susan. 1985. Coming to Terms with the Short Story. Baton Rouge: Louisiana State University Press.

Makala, Melissa Edmundson. 2013. Women's Ghost Literature in Nineteenth-Century Britain. Cardiff: University of Wales Press.

Mangham, Andrew. 2007. Violent Women and Sensation Fiction: Crime, Medicine, and Victorian Popular Culture. New York: Palgrave. DOI: https://doi.org/10.1057/9780230286993

Mangham, Andrew, ed. 2013. The Cambridge Companion to Sensation Fiction. Cambridge: Cambridge University Press. DOI: https://doi.org/10.1017/CCO9780511675744

Mansel, H.L. 1863. "Sensation Novels.” Quarterly Review, 113: 481-514.

Maunder, Andrew, ed. 2007. The Facts on File Companion to the British Short Story. New York: Facts on File.

Miller, D.A. 1988. The Novel and the Police. Berkeley: University of California Press.

O'Brien Hill, Georgina. 2011. Review of A Companion to Sensation Fiction, by Pamela K. Gilbert, ed. The Wilkie Collins Journal, 11. https://wilkiecollinssociety.org/a-companion-to-sensation-fiction/

Ogawa, Kimiyo. 2007. “'Strangers within in our Gates' in Le Fanu's Uncle Silas.” Journal of Irish Studies, 22: 16-23.

Orel, Harold. 1986. The Victorian Short Story: Development and Triumph of a Literary Genre. Cambridge: Cambridge University Press. 
Peterson, Audrey. 1984. Victorian Masters of Mystery: From Wilkie Collins to Conan Doyle. New York: Frederick Ungar Publishing.

“Recent Novels: their Moral and Religious Teaching." 1866. London Quarterly Review, 27 (October): 100-24.

Rev. of The Moonstone. [1868] 1974. Lippincott's Magazine, 2 (December): 679-80. In Wilkie Collins: The Critical Heritage, edited by Norman Page, 179-81. London: Routledge.

Rev. of The Queen of Hearts. [1859] 1974. Saturday Review, 8 (22 October): 487-8. In Wilkie Collins: The Critical Heritage, edited by Norman Page, 74-7. London: Routledge

Rev. of The Woman in White. [1860] 1974. Saturday Review, 10 (25 August): 249-50. In Wilkie Collins: The Critical Heritage, edited by Norman Page, 83-7. London: Routledge.

Roberts, Brittany. 2018. "Mary Elizabeth Braddon's 'Ralph the Bailiff': Speaking Truth to Madness." Victorian Review, vol. 44, no. 2: 166-70. DOI: doi:10.1353/vcr.2019.0013

Smajić, Srdjan. 2010. Ghost-Seers, Detectives, and Spiritualists: Theories of Vision in Victorian Literature and Science. Cambridge: Cambridge University Press. DOI: https://doi.org/ 10.1017/CBO9780511712012

Tillotson, Kathleen. 1969. “The Lighter Reading of the Eighteen-Sixties.” In Wilkie Collins, The Woman in White, edited by Anthea Trodd and Kathleen Tillotson, ix-xxvi. Boston: Houghton.

Victorian Short Fiction Project. Brigham Young University, https://vsfp.byu.edu/

Wallace, Diana. 2004. "Uncanny Stories: The Ghost Story as Female Gothic." Gothic Studies, vol. 6, no. 1: 57-68. DOI: https://doi.org/10.7227/GS.6.1.6

Wood, Ellen. 1853. “St. Martin's Eve.” New Monthly Magazine. vol. 99 (November): 327-42.

Wood, Ellen. 1866. St. Martin's Eve. London: Tinsley Brothers.

Zuber, Devin P. 2006. "Swedenborg and the Disintegration of Language in Sheridan Le Fanu's Sensation Fiction." In Victorian Sensations: Essays on a Scandalous Genre, edited by Harrison and Fantina, 74-84. Columbus: Ohio State University Press. 